\title{
Short communication: Staphylococcus aureus isolated from colostrum of dairy heifers represent a closely related group exhibiting highly homogeneous genomic and antimicrobial resistance features
}

\author{
Ueli Stalder, ${ }^{*}$ Roger Stephan, ${ }^{*}$ Sabrina Corti, ${ }^{*}$ Maren Bludau, $\dagger$ Ariane Maeschli, $\dagger$ Peter Klocke, $\dagger^{1}$ \\ and Sophia Johler*2 \\ *Institute for Food Safety and Hygiene, Vetsuisse Faculty University of Zurich, 8057 Zurich, Switzerland \\ †Forschungsinstitut für biologischen Landbau, 5070 Frick, Switzerland
}

\section{ABSTRACT}

In heifers, intramammary infections caused by Staphylococcus aureus affect milk production and udder health in the first and subsequent lactations, and can lead to premature culling. Not much is known about Staph. aureus isolated from heifers and it is also unclear whether or not these strains are readily transmitted between heifers and lactating herd mates. In this study, we compared phenotypic characteristics, spa types, and DNA microarray virulence and resistance gene profiles of Staph. aureus isolates obtained from colostrum samples of dairy heifers with isolates obtained from lactating cows. Our objective was to (1) characterize Staph. aureus strains associated with mastitis in heifers and (2) determine relatedness of Staph. aureus strains from heifers and lactating cows to provide data on transmission. We analyzed colostrum samples of 501 heifers and milk samples of 68 lactating cows within the same herd, isolating 48 and 9 Staph. aureus isolates, respectively. Staphylococcus aureus strains from heifers, lactating herd mates, and an unrelated collection of 78 strains from bovine mastitis milk of mature cows were compared. With 1 exception each, characterization of all strains from heifers and lactating cows in the same herd yielded highly similar phenotypic and genotypic results. The strains were Staphaurex latex agglutination test negative (Oxoid AG, Basel, Switzerland) and belonged to agr type II, CC705, and spa types t529 and t12926. They were susceptible to all antimicrobial agents tested. In contrast, the strains from mature cows in other herds were spread across different clonal complexes, spa types, and SplitsTree clusters (http://www. splitstree.org/), thus displaying a far higher degree of heterogeneity. We conclude that strains isolated from colostrum of heifers and mastitis milk of lactating cows

\footnotetext{
Received November 14, 2013.

Accepted April 24, 2014.

${ }^{1}$ Present address: bovicare GmbH, 14473 Potsdam, Germany.

${ }^{2}$ Corresponding author: sophia.johler@uzh.ch
}

in the same herd feature highly similar phenotypic and genomic characteristics, suggesting persistence of the organism during the first and potentially subsequent lactations or transmission between heifers and mature herd mates.

Key words: Staphylococcus aureus, dairy heifer, bovine mastitis, genotyping

\section{Short Communication}

Heifer mastitis leads to considerable financial losses in the dairy industry, as it affects not only future milk performance and udder health, but also leads to premature culling (Compton et al., 2007; Piepers et al., 2010). To date, it is still poorly understood, which sources of infection and routes of transmission play a role in Staphylococcus aureus mastitis in heifers. Heifers have never been milked and have, thus, not been exposed to the milking process and vacuum, which represent major risk factors for contagious mastitis in lactating cows. However, Staph. aureus can be detected in milk samples of up to $15 \%$ of heifers prepartum and in up to $8 \%$ of heifers at first parturition (Fox, 2009). Whereas heifers were suggested to represent a reservoir of Staph. aureus to uninfected herd mates (Roberson et al., 1994), another study suggested that the udder of lactating cows might be an infection source of contagious major pathogens for heifers (Piepers et al., 2011). In a recent review, De Vliegher et al. (2012) summarized the controversial discussion on transmission of Staph. aureus between heifers and mature cows and declared the need for further studies using strain typing.

In this study, we compare DNA microarray profiles and spa types, as well as phenotypic characteristics of Staph. aureus isolates obtained from colostrum samples of dairy heifers to isolates obtained from mastitis milk of lactating cows. Our objective was to (1) characterize Staph. aureus strains associated with mastitis in heifers and (2) determine the relatedness of Staph. aureus strains from heifers and lactating herd mates to provide data on transmission. 
Colostrum samples of 501 heifers form a randomized selection of 72 farms in Switzerland were collected. Sampling was performed within $24 \mathrm{~h}$ postpartum. In addition, a total of 68 samples from lactating cows within the same herd, including first-lactation animals, were taken on 7 farms, which harbored heifers that had been tested positive for Staph. aureus. Only milk from lactating cows with clinical signs of mastitis or milk that had been tested positive in the California mastitis test was collected. For all tested cows, quarter milk samples were collected by the farmers. We compared strains from heifers $(\mathbf{H})$ and lactating cows $(\mathbf{L C})$ within the same herd to strains from an unrelated collection (C) of 78 Staph. aureus strains that were used in a comprehensive study investigating bovine mastitis isolates from mature cows in Switzerland (Moser et al., 2013).

We characterized the strains using the latex agglutination test, antimicrobial susceptibility testing, spa typing, and a DNA microarray. A Staphaurex latex agglutination test (SLAT) was performed using the Staphaurex Plus kit (Oxoid AG, Basel, Switzerland) according to the manufacturer's instructions. For susceptibility testing, the following agents were tested: ampicillin $(10 \mu \mathrm{g})$, amoxicillin $(20 \mu \mathrm{g})$ with clavulanic acid $(10 \mu \mathrm{g})$, cephalothin $(30 \mu \mathrm{g})$, ceftiofur $(30 \mu \mathrm{g})$, erythromycin $(15 \mu \mathrm{g})$, cefoxitin $(30 \mu \mathrm{g})$, gentamicin $(10$ $\mu \mathrm{g})$, kanamycin $(30 \mu \mathrm{g})$, cefalexin-kanamycin (15-30 $\mu \mathrm{g})$, penicillin (10 IU), and penicillin-novobiocin (10 IU-30 $\mu \mathrm{g})$. Disks containing cefalexin-kanamycin (Ubrolexin) were provided by Boehringer Ingelheim GmbH (Basel, Switzerland); disks containing ceftiofur, penicillin, and penicillin-novobiocin were obtained from Oxoid AG; and all other disks were provided by Becton Dickinson AG (Basel, Switzerland). Disk diffusion was performed on Mueller-Hinton agar and Staph. aureus ATCC 25923 was used as a quality control. Strains were classified according to Clinical and Laboratory Standards Institute standard protocols (CLSI, 2008), except for cefalexin-kanamycin, for which preliminary interpretive breakpoints recommended by Pillar et al. (2009) were used. The spa types were determined as previously described (Wattinger et al., 2012). For the DNA microarray assay, we used the Staph. aureus genotyping kit (Alere Technologies GmbH, Jena, Germany) to detect the absence or presence of 333 genes and their allelic variants and to assign strains to clonal complexes. Microarray data from a comprehensive study by Moser et al. (2013) on characteristic features of Staph. aureus isolated from mastitis milk of lactating cows (C) in Switzerland served as a control to assess unique features among the virulence and resistance genes of Staph. aureus strains isolated from H and LC in the same herd. For statistical analysis, the distribution of genes was compared based on DNA microarray results using SPSS Statistics 21 software (SPSS Inc., Chicago, IL) to run the Pearson $\chi^{2}$ test to identify significant associations between the source of the strains and the presence of the genes. The Fisher exact test was used in case the expected count was less than 5 . Results were considered statistically significant for $P<0.05$.

We isolated Staph. aureus from 10\% of H colostrum samples and $13 \%$ of LC mastitis milk samples. Isolates exhibiting identical microarray patterns, as well as identical CC and spa type assignments were considered to represent the same strain (Supplemental Table S1; http://dx.doi.org/10.3168/jds.2013-7721). Six Hstrains were isolated in duplicate (H_5, H_6, H_7, H_8, H_15, and $\left.\mathrm{H} \_22\right), 1$ LC strain in triplicate (LC_7), and 2 strains could be found among both $\mathrm{H}$ and LC herd mates (H_15 = LC_2 and H_22 = LC_1). Five of the 6 strains that were isolated in duplicate among $\mathrm{H}$ were isolated at farm $\mathrm{A}$ as well as from at least $1 \mathrm{H}$ or $\mathrm{LC}$ in another farm (farms B, C, D, and E). Interestingly, an additional $7 \mathrm{H}$ strains (H_16 to $\mathrm{H} \_21$ and $\mathrm{H} \_29$ ) were isolated on farm A.

With 1 exception each, characterization of all strains from $\mathrm{H}$ and LC in the same herd yielded highly similar phenotypic and genotypic results. The strains were SLAT(-) and belonged to agr type II, CC705, and spa types t529 $(\mathrm{n}=38)$ and t12926 $(\mathrm{n}=1)$. They were also susceptible to all antimicrobial agents tested in the disk diffusion assay. In addition, this group of strains formed a highly homogeneous subcluster within the CC705 cluster of the SplitsTree software (http://www. splitstree.org/; Supplemental Figure S1; http://dx.doi. org/10.3168/jds.2013-7721), exclusively comprising $\mathrm{H}$ and LC strains. In contrast, the $\mathrm{C}$ strains were spread across different clonal complexes and SplitsTree clusters, thus displaying a far higher degree of heterogeneity. Only H_14 and LC_7 were not integrated into the highly homogeneous group and exhibited a SLAT $(+)$ phenotype, as well as differing clonal complexes and spa types (H_14: CC97 and t267; LC_7: CC45 and t7061). Whereas H_14 was susceptible to all tested antibiotic agents, LC_7 exhibited resistance to penicillin and ampicillin.

A selection of DNA microarray results is listed in Table 1 and full microarray results are provided as supplemental data (Supplemental Table S2; http://dx.doi. org/10.3168/jds.2013-7721). Overall, strains from H and LC herd mates exhibited highly similar prevalence rates of most resistance and virulence genes, whereas various statistically significant differences were detected when comparing these rates to the respective prevalences in the control strains. Among others, $\mathrm{H}$ and LC strains differed from $\mathrm{C}$ strains regarding the prevalence of various allelic variants of genes encoding adhesins, proteins involved in immunevasion, enterotoxins, and 
Table 1. Comparison of prevalence rates (\%) of virulence and antibiotic resistance genes among Staphylococcus aureus strains isolated from milk of heifers $(\mathrm{H})$, lactating cows $(\mathrm{LC})$ within the same herd, and mature cows used as a control (C)

\begin{tabular}{|c|c|c|c|c|c|}
\hline Group & Gene/probe & Function & $\begin{array}{c}\mathrm{H} \\
(\mathrm{n}=32)\end{array}$ & $\begin{array}{c}\mathrm{LC} \\
(\mathrm{n}=7)\end{array}$ & $\begin{array}{c}\mathrm{C} \\
(\mathrm{n}=78)\end{array}$ \\
\hline Resistance $^{1}$ & $\mathrm{blaI} / R / Z$ & $\beta$-Lactamase & $0^{* \mathrm{C}}$ & 14 & $13^{* \mathrm{H}}$ \\
\hline \multirow{3}{*}{ Enterotoxin $^{2}$} & ORF CM14 & Enterotoxin-like protein & $97^{* \mathrm{C}}$ & 86 & $53^{* \mathrm{H}}$ \\
\hline & seg & Enterotoxin G & $97^{* \mathrm{C}}$ & 71 & $65^{* \mathrm{H}}$ \\
\hline & sei & Enterotoxin I & $97^{* \mathrm{C}}$ & 100 & $65^{* \mathrm{H}}$ \\
\hline \multirow{5}{*}{ Virulence } & tst1 & Toxic shock syndrome toxin & 13 & 0 & 8 \\
\hline & et $A / B / C$ & Exfoliative toxins & 0 & 0 & 0 \\
\hline & aur & Aureolysin & 100 & 86 & 97 \\
\hline & splE & Serine protease $\mathrm{E}$ & $3^{* \mathrm{C}}$ & 0 & $35^{* \mathrm{H}}$ \\
\hline & $\operatorname{lukM} / \mathrm{lukF-PV}(\mathrm{P} 83)$ & Bovine leukocidin & $100 * \mathrm{C}$ & 86 & $72^{* \mathrm{H}}$ \\
\hline
\end{tabular}

${ }^{1}$ We $\operatorname{did}$ not detect the resistance genes mecA, erm $A / B / C, \operatorname{tet} K, \operatorname{lnu} A, \operatorname{msr} A$, mef $A, \operatorname{mph} C, \operatorname{vat} A / B, \operatorname{vga} A / B, \operatorname{van} A / B / Z$, fosB, aacA-aphD, aadD, aphA3, sat, dfrS1, far1, mupA, tetK, cat, fexA, cfr, and qacA/C among $\mathrm{H}$ and $\mathrm{LC}$ within the same herd.

${ }^{2}$ We did not detect the following genes encoding staphylococcal enterotoxins or enterotoxin-like superantigens in $\mathrm{H}$ or LC strains: sea, seb, sed, see, seh, selj, selk, selq, and selr.

*Statistically significant differences $(P<0.05)$.

enterotoxin-like superantigens as well as genes involved in capsule and biofilm formation (Supplemental Table S2).

In the latex agglutination test, the vast majority of $\mathrm{H}$ and LC strains exhibited a $\operatorname{SLAT}(-)$ phenotype. Staphaurex is a latex agglutination-based test used to confirm putative Staph. aureus isolates. In our study, Staph. aureus CC705 isolates could not be detected using the Staphaurex kit, which is consistent with recent findings (Stutz et al., 2011; Moser et al., 2013).

Risk factors and prevention strategies for heifer mastitis have been described in detail (Waage et al., 2001; Fox, 2009; Anderson et al., 2012); however, information on genomic characteristics of Staph. aureus from heifers is scarce and transmission of the organism between heifers and lactating cows is controversially discussed (Roberson et al., 1994; Piepers et al., 2011; De Vliegher et al., 2012). In our study, characterization of Staph. aureus strains isolated from colostrum of $\mathrm{H}$ and milk of LC herd mates yielded highly similar phenotypic and genotypic results not only for animals within the same herd, but across all tested herds. The strains were SLAT $(-)$; belonged to agr type II, CC705 (former CC151), and spa type t529; and were susceptible to all antimicrobial agents. However, this homogeneous group differed significantly from strains isolated from mature cows in other herds (Moser et al., 2013). As the farms investigated in the study by Moser et al. (2013) and the farms in which we isolated Staph. aureus from $\mathrm{H}$ colostrum are spread throughout Switzerland, the high homogeneity among $\mathrm{H}$ and LC strains cannot be attributed to close proximity of the respective farms. The closely related group of Staph. aureus detected in our study may possess a crucial competitive advantage needed for persistence within the udder of $\mathrm{H}$ throughout the first and potentially subsequent lactations. A SLAT (-) phenotype could favor persistence in the udder, as these strains are thought to be less virulent than $\mathrm{SLAT}(+)$ isolates and cause a weaker immune response (Zbinden et al., 2014). In addition, SLAT(-) strains are not recognized as Staph. aureus in routine diagnostic procedures, as they yield false-negative results in the Staphaurex test and could, therefore, be misclassified as coagulase-negative Staph. aureus.

We conclude that strains isolated from colostrum of $\mathrm{H}$ and mastitis milk of $\mathrm{LC}$ in the same herd feature highly similar phenotypic and genomic characteristics, suggesting either transmission between heifers and mature herd mates or persistence within the udder throughout the first and subsequent lactations. Further studies using high-resolution techniques such as the DNA microarray are needed to track a strain from the same cow over several lactations.

\section{ACKNOWLEDGMENTS}

We express our gratitude to the farmers that participated in this study. This project was partly funded by the Swiss Army.

\section{REFERENCES}

Anderson, K. L., R. Lyman, K. Moury, D. Ray, D. W. Watson, and M. T. Correa. 2012. Molecular epidemiology of Staphylococcus aureus mastitis in dairy heifers. J. Dairy Sci. 95:4921-4930.

CLSI (Clinical and Laboratory Standards Institute). 2008. Performance standards for antimicrobial disk and dilution susceptibility 
tests for bacteria isolated from animals. Vol. 28. 3rd ed. CLSI, Wayne, PA.

Compton, C. W. R., C. Heuer, K. Parker, and S. McDougall. 2007. Risk factors for peripartum mastitis in pasture-grazed dairy heifers. J. Dairy Sci. 90:4171-4180.

De Vliegher, S., L. K. Fox, S. Piepers, S. McDougall, and H. W. Barkema. 2012. Invited review: Mastitis in dairy heifers: Nature of the disease, potential impact, prevention, and control. J. Dairy Sci. 95:1025-1040.

Fox, L. K. 2009. Prevalence, incidence and risk factors of heifer mastitis. Vet. Microbiol. 134:82-88.

Moser, A., R. Stephan, S. Corti, and S. Johler. 2013. Comparison of genomic and antimicrobial resistance features of latex agglutination test-positive and latex agglutination test-negative Staphylococcus aureus isolates causing bovine mastitis. J. Dairy Sci. 96:329-334.

Piepers, S., G. Opsomer, H. W. Barkema, A. de Kruif, and S. De Vliegher. 2010. Heifers infected with coagulase-negative staphylococci in early lactation have fewer cases of clinical mastitis and higher milk production in their first lactation than noninfected heifers. J. Dairy Sci. 93:2014-2024.

Piepers, S., K. Peeters, G. Opsomer, H. W. Barkema, K. Frankena, and S. De Vliegher. 2011. Pathogen group specific risk factors at herd, heifer and quarter levels for intramammary infections in early lactating dairy heifers. Prev. Vet. Med. 99:91-101.
Pillar, C. M., L. Goby, D. Draghi, P. Grover, and C. Thornsberry 2009. Evaluating the in vitro susceptibility of bovine mastitis pathogens to a combination of kanamycin and cefalexin: Recommendations for a disk diffusion test. J. Dairy Sci. 92:6217-6227.

Roberson, J. R., L. K. Fox, D. D. Hancock, C. C. Gay, and T. E. Besser. 1994. Coagulase-positive Staphylococcus intramammary infections in primiparous dairy cows. J. Dairy Sci. 77:958-969.

Stutz, K., R. Stephan, and T. Tasara. 2011. SpA, ClfA, and FnbA genetic variations lead to Staphaurex test-negative phenotypes in bovine mastitis Staphylococcus aureus isolates. J. Clin. Microbiol. 49:638-646.

Waage, S., S. A. Ødegaard, A. Lund, S. Brattgjerd, and T. Røthe. 2001. Case-control study of risk factors for clinical mastitis in postpartum dairy heifers. J. Dairy Sci. 84:392-399.

Wattinger, L., R. Stephan, F. Layer, and S. Johler. 2012. Comparison of Staphylococcus aureus isolates associated with food intoxication with isolates from human nasal carriers and human infections. Eur. J. Clin. Microbiol. Infect. Dis. 31:455-464.

Zbinden, C., R. Stephan, S. Johler, N. Borel, J. Bünter, R. M. Bruckmaier, and O. Wellnitz. 2014. The inflammatory response of primary bovine mammary epithelial cells to Staphylococcus aureus strains is linked to the bacterial phenotype. PLoS One 9:e87374. 